\title{
Monitoring of Frequency and Antimicrobial Susceptibility of Pathogens on the Hands of Healthcare Workers in a Tertiary Hospital
}

\author{
Athanasios Tselebonis, Evangelia Nena, Christos Nikolaidis, Theocharis Konstantinidis, Christos \\ Kontogiorgis, Maria Panopoulou, Theodore C. Constantinidis
}

Democritus University of Thrace, Alexandroupolis, Greece

Correspondence: E. Nena, Laboratory of Hygiene and Environmental Protection, Medical School, Democritus University of Thrace, 6th Km AlexandroupolisMakris, Dragana 68100

Alexandroupolis, Greece E-mail: enena@med.duth.gr Tel: +302551030638

Received: 23 Dec 2015

Accepted: 20 June 2016

Published Online: 8 Aug 2016

Published: 30 Sept 2016

Key words: hospital hygiene, hand samples, drug resistance, healthcare workers

Citation: Tselebonis A, Nena E, Nikolaidis C, Konstantinidis T, Kontogiorgis C, Panopoulou M, Constantinidis TC. Monitoring of Frequency and Antimicrobial Susceptibility of Pathogens on the hands of Healthcare Workers in a Tertiary Hospital.

Folia Medica 2016;58(3);200-205 doi: 10.1515/folmed-2016-0028
Objective: To monitor microbes, focusing on drug resistance, on the hands of the personnel of four departments of a tertiary hospital (ICU, neonatal unit, internal medicine ward and surgical ward) and explore differences between departments, professions and genders.

Materials and methods: Hand sampling from 125 healthcare employees was conducted followed by isolation, identification and antibiotic resistance profiling of different microbial species.

Results: Staphylococcus spp was the most prevalent microbe (76/125, 60.8\%), followed by different Gram-negative pathogens (45.6\%). ICU employees had a significant probability to have Gram-negative contamination [OR $3.627(95 \% \mathrm{Cl}$ 1.220-10.782)], independently of gender or profession. Staphylococcus spp presence was associated with working in the internal medicine ward [OR 6.976 (95\% $\mathrm{Cl} 1.767-25.540)$ ] and the surgical ward [OR 5.795 (95\% Cl 1.586-21.178)]. Staphylococcus spp was more prevalent in males vs. females $(81.3 \%$ vs. $54.9 \%, p=0.008)$ and in medical vs. nursing personnel (76.9\% vs. $54.8, \mathrm{p}=0.019)$.

In the majority of Gram-negative isolates (56.1\%), at least one multi-drug resistant (MDR) or extensively drug resistant (XDR) strain was isolated. A statistically significant higher prevalence of XDR Gram-negative microbes was found on the hands of nursing personnel ( $22.2 \%$ vs. $2.3 \%$ for medical doctors, $p=0.014)$. Only 2 methicillin resistant Staphylococcus Aureus (MRSA) out of the 12 Staphylococcus aureus positive samples were identified.

Conclusions: Employees in the ICU are more prone to Gram-negative and not to Gram-positive hand contamination. MDR and XDR pathogens are prevalent, and are associated with nursing profession.

\section{INTRODUCTION}

Healthcare-associated infections are a significant burden in public health as they are associated with increased morbidity and mortality, prolongation of hospital stay, and compromise of survival of immunosuppressed patients. ${ }^{1}$ Thus, compliance with hand hygiene guidelines is necessary since contamination via hands of healthcare providers plays a cardinal role in the transmission of diseases in healthcare settings. $^{2}$ This is of major importance, especially for multi-drug resistant pathogens, which are currently one of the biggest challenges in hospital hygiene. ${ }^{3}$

\section{AIM}

The aim of this study was to monitor microbial species, focusing on their drug resistance on the hands of medical and nursing personnel, working in four different departments of a tertiary hospital and to explore possible differences between location, profession and gender of the employees.

\section{METHODS}

\section{SAMPLE COLLECTION}

The study was conducted in a tertiary university hospital of NE Greece for a period of 12 months (from March 2013 to February 2014). Samples of 
animate sources (hands) were collected on a monthly basis, from the employees in four different hospital departments, namely the Intensive Care Unit (ICU), the neonatal unit, the internal medicine ward, and the surgical ward.

Briefly, the procedure was the following: on a monthly basis, members of the research group made unannounced visits to the abovementioned departments, recruiting the personnel on shift to participate, by providing hand samples during their daily routine duties and without having previously their hands washed.

Sample collection was performed according to the following protocol: a sterile bag (Stomacher 400 Classic; Seward) containing $500 \mathrm{~mL}$ of brain-heart infusion broth was used in which the recruited individuals immersed and rubbed their hands for about 60 seconds. The sampling fluid was collected in a sterilized container and microbiological analyses were conducted according to standard procedures.

Microbiological METHOdS AND CHARACTERIZATION OF ANTIBIOTIC SUSCEPTIBILITY

Nutrient agar (Oxoid), MacConkey agar (Merck), Slanetz \& Bartley Medium (Oxoid), and BairdParker agar (Merck) were used for the isolation and enumeration of: i) total aerobic counts, ii) Gram-negative microorganisms, iii) Enterococci and iv) Staphylococci, respectively. Pure cultures were prepared on blood or MacConkey agar and identification to the species level, as well as antibiotic sensitivity analysis, were performed by a VITEK-2 automated system (Biomérieux). Characterization of bacterial isolates as multidrug-resistant (MDR), or extensively drug-resistant (XDR) was carried out according to standardized international terminology proposed by the joint initiative of the European Centre for Disease Prevention and Control (ECDC) and the Centers for Disease Control and Prevention $(\mathrm{CDC}) .{ }^{4}$

\section{Statistical ANALYSis}

According to the assessment of normality of distribution by the Kolmogorov - Smirnov test, nonparametric statistics were applied. Chi-squared test was used for assessing differences in proportions and Kruskal-Wallis analysis was used for comparisons across different sample groups. Binary logistic regression analysis was applied in order to detect factors that might predict the presence of a particular microbial isolate. More specifically, gender (females used as reference), profession (nurses used as reference) and department (neonatal unit used as reference), were entered in this regression model and were evaluated as potential predictive factors for the presence of pathogens. The level of significance was set at $\mathrm{p}$ value $<0.05$. All statistical analyses were conducted with IBM SPSS v. 17.0.

The study protocol received approval by the Institutional Ethics Committee.

\section{RESULTS}

During the course of the study, 125 healthcare employees, 81 nurses $(64.8 \%)$ and 44 medical doctors $(35.2 \%)$ were examined, as described in the Material and methods. Table 1 displays the departments they were working, as well as the gender distribution by department and profession.

Staphylococcus spp. was the most prevalent isolate $(76 / 125,60.8 \%)$ with median value: $194 \mathrm{CFU}$ (IQR 41-1000 CFU). Twelve Staphylococcus aureus strains were isolated in the study sample (12/125 $=9.6 \%$ ), while Enterococcus $s p$ was identified in 28 employees (22.4\%), median value $14 \mathrm{CFU}$ (IQR 3-61 CFU).

In 57 hand samples (45.6\%), Gram-negative microbes were also isolated, most of them referred to Acinetobacter baumanni $(\mathrm{n}=29)$ and Klebsiella pneumoniae $(\mathrm{n}=21)$, with median value $18 \mathrm{CFU}$ (IQR 4-110 CFU). The rest of the Gram-negative microorganisms which were isolated, included Escherichia coli, Pseudomonas aeruginosa, Pseudomonas stutzeri, Pseudomonas luteola, Pseudomonas putida, Enterobacter cloacae, Pantoea agglomerans, Moraxella spp., and Aeromonas salmonicida.

Logistic regression was applied in order to identify factors predicting the isolation of strains on the hands of the personnel. As it was found, the odds were significantly higher for employees working in ICU to have an identifiable strain (either Grampositive or -negative) [OR of 3.029 (95\% CI: 1.0618.647)]. No other factor (gender or profession) was found to be statistically significant. Likewise, the presence of Gram-negative pathogens in the hand samples was associated only with working in the ICU [OR 3.627 (95\% CI 1.220-10.782)]. Results are displayed in Table 2.

The presence of Staphylococcus spp. was associated with working in the internal medicine ward [OR 6.976 (95\% CI 1.767-25.540)] and the surgical ward [OR 5.795 (95\% CI 1.586-21.178)] (Table 2). Further analysis showed that Staphylococcus spp. was isolated more prevalently on the hands of male 
vs. female workers $(81.3 \%$ vs. $54.9 \%$ respectively, chi-squared $6.938, \mathrm{p}=0.008$ ) and on the hands of medical vs. nursing personnel $(76.9 \%$ vs. $54.8 \%$, chi-squared 5.540, $\mathrm{p}=0.019$ )

In a significant number of participants (32 out of $57,56.1 \%$ ) with Gram-negative isolates, at least one multi-drug resistant (MDR) or extensively drug resistant (XDR) strain was isolated. Of note is that in 4 samples (7\%) two different MDR strains were simultaneously identified. MDR strains referred to Acinetobacteer baumanii $(\mathrm{n}=8)$ and Klebsiella pneumoniae $(\mathrm{n}=5)$, while the XDR strains referred to Acinetobacter baumanii $(\mathrm{n}=19)$. More specifically, in 17 employees (29.8\%) at least one XDR strain was identified while two employees had two different XDR strains.

Regarding resistance of Gram-positive bacteria, only in 2 out of the 12 positive for Staphylococcus aureus hand samples, resistance to methicillin was found (Methicillin Resistant Staphylococcus Aureus MRSA), resulting in a prevalence of $2 / 125=1.6 \%$. Interestingly, a statistically significant difference in the prevalence of XDR Gram-negative microbes was found between medical and nursing personnel. More specifically, XDR strains were detected only in $2.3 \%$ of medical doctors, while this percentage was significantly higher (22.2\%) among nurses (chi-squared 6.076, $\mathrm{p}=0.014$ ).

Table 1. Distribution of the studied health-care employees by profession and gender

\begin{tabular}{lccccccccc}
\hline & \multicolumn{2}{c}{ Included healthcare workers } & \multicolumn{2}{c}{ Medical Doctors } & \multicolumn{3}{c}{ Nurses } \\
\hline Department & Total & Males & Females & Total & Males & Females & Total & Males & Females \\
\hline $\begin{array}{l}\text { Internal Medicine } \\
\text { Ward }\end{array}$ & 25 & 9 & 16 & 10 & 6 & 4 & 15 & 3 & 12 \\
Surgical Ward & 26 & 10 & 16 & 9 & 8 & 1 & 17 & 2 & 15 \\
ICU & 49 & 19 & 30 & 19 & 16 & 3 & 30 & 3 & 27 \\
Neonatal Unit & 25 & 1 & 24 & 6 & 0 & 6 & 19 & 1 & 18 \\
Total & 125 & 39 & 86 & 44 & 30 & 14 & 81 & 9 & 72 \\
\hline
\end{tabular}

Table 2. Odds Ratios and 95\% confidence intervals for different types of hand contamination in different departments of the hospital versus the neonatal unit

OR $\quad 95 \% \mathrm{CI} \quad \mathrm{P}$

Presence of an identifiable microbial strain in general

Internal Medicine ward vs. Neonatal Unit

1.398

$0.434-4.499$

0.574

Surgical Ward vs. Neonatal Unit 


\section{Presence of a gram negative strain}

Internal Medicine ward vs. Neonatal

Unit
0.934
$0.263-3.323$
0.916

Surgical Ward vs.

Neonatal Unit

2.554

$0.774-8.424$

0.124

ICU vs. Neonatal Unit

3.627

$1.220-10.782$

0.020

Presence of Staphylococcus spp.

\begin{tabular}{lccc}
\hline $\begin{array}{l}\text { Internal Medicine } \\
\text { ward vs. Neonatal }\end{array}$ & 6.976 & $1.767-27.540$ & 0.006 \\
Unit & & & \\
$\begin{array}{l}\text { Surgical Ward vs. } \\
\text { Neonatal Unit }\end{array}$ & 5.795 & $1.586-21.178$ & 0.008 \\
& & & 0.549 \\
ICU vs. Neonatal Unit & 1.384 & $0.478-4.001$ & \\
\hline
\end{tabular}

\section{DISCUSSION}

The present study monitors different microbial species in the hand samples of healthcare workers of four different departments in a tertiary hospital, assessing at the same time their drug resistance characteristics. As it was demonstrated, working in the ICU was associated with a higher risk for hand contamination in general, as well as with a higher risk for Gram-negative pathogens. On the contrary, Gram-positive infection was associated with working in the internal medicine ward followed by working in the surgical ward. Additionally, Staphylococcus spp infection was associated with male gender and medical profession, while the amount of drug resistant Gram-negative bacteria, both MDR or XDR, was higher in samples of nursing staff.

A recent study conducted in USA reported a $6.2 \%$ prevalence of MRSA hand samples of 209 healthcare workers, ${ }^{5}$ certainly a higher percentage than that found in our study. On the other hand, a study on 50 healthcare workers in Malaysia reported a prevalence of $6 \%$ of Staphylococcus aureus contamination, however it did not identify any MRSA strain. ${ }^{6}$ The rest of the flora isolated in this study, did not differ significantly in comparison to our study sample. A previously conducted study in Ethiopia reported a significant difference in Staphylococcus aureus contamination between nurses and medical doctors ( $13.6 \%$ vs. $2.3 \%$, respectively, $\mathrm{p}=0.044)$ and a $6.2 \%$ MRSA hand carriage in total. ${ }^{7}$ Regarding prevalence of MDR Gram-negative pathogens this was $15.8 \%$, significantly higher than that reported by O'Fallon et al. among healthcare workers in USA $(7.7 \%) .{ }^{8}$ In an old study conducted in a European hospital Staphylococcus aureus (10.5\%) and Gramnegative bacilli $(14.5 \%)$ were isolated, although the predominant flora was normal skin flora i.e. coagulase-negative staphylococci, Corynebacterium spp, and Micrococcus spp..$^{9}$

Previous studies have highlighted the importance of hand hygiene in restricting transmission of infections in healthcare settings. ${ }^{10-12}$ Indeed, implementation of strategies aiming at improving hand sanitation, such as hand washing, use of disinfectants and use of gloves was proved to be successful in reducing nosocomial infections. ${ }^{13-16}$ 
The major strength of the present study is that different microbial species colonizing the hands of healthcare professionals were documented for the first time in this country, with emphasis placed on drug resistance. Moreover, different professions and settings within the same hospital environment were also examined so as to detect possible predictive factors for specific microbial contamination and to design strategies with special targets.

In summary, personnel working in the ICUs and Internal Medicine wards are more prone to hand contamination, with Staphylococcus infection being more prevalent among medical professionals. Unfortunately, multi-drug and especially XDR pathogens are also prevalent, and they are mostly associated with the nursing profession. This could be explained by more frequent contact with patients, and other unaccounted for factors. Special actions should be therefore undertaken aiming at specific professional groups and settings taking into consideration the different levels of compliance for hand hygiene practices. ${ }^{17}$

\section{REFERENCES}

1. Sydnor ER, Perl TM. Hospital epidemiology and infection control in acute-care settings. Clin Microbiol Rev 2011;24:141-73.

2. Pincock T, Bernstein P, Warthman S, et al. Bundling hand hygiene interventions and measurement to decrease health care-associated infections. Am J Infect Control 2012;40(4 Suppl 1):S18-27.

3. Gootz TD. The global problem of antibiotic resistance. Crit Rev Immunol 2010;30:79-93.

4. Magiorakos AP, Srinivasan A, Carey RB, et al. Multidrug-resistant, extensively drug-resistant and pandrug-resistant bacteria: an international expert proposal for interim standard definitions for acquired resistance. Clin Microbiol Infect 2012;18:268-81.

5. Colburn NE, Cadnum J, Flannery E, et al. Perception vs Reality: Methicillin-Resistant Staphylococcus aureus Carriage Among Healthcare Workers at a Veterans Affairs Medical Center. Infect Control Hosp Epidemiol 2015 Nov 3:1-3. [Epub ahead of print]

6. Wong JL, Siti Azrin AH, Narizan MI, et al. Back to basic: bio-burden on hands of health care personnel in tertiary teaching hospital in Malaysia. Trop Biomed 2014;31:534-9.

7. Gebreyesus A, Gebre-Selassie S, Mihert A. Nasal and hand carriage rate of methicillin resistant Staphylococcus aureus (MRSA) among health care workers in Mekelle Hospital, North Ethiopia. Ethiop Med J 2013;51:41-7.

8. O'Fallon E, Schreiber R, Kandel R, et al. Multidrugresistant gram-negative bacteria at a long-term care facility: assessment of residents, healthcare workers, and inanimate surfaces. Infect Control Hosp Epidemiol 2009;30:1172-9.

9. Pittet D, Dharan S, Touveneau S, et al. Bacterial contamination of the hands of hospital staff during routine patient care. Arch Intern Med 1999;159:821-6.

10. Pittet D, Hugonnet S, Harbarth S, et al. Effectiveness of a hospital-wide programme to improve compliance with hand hygiene. Infection Control Programme. Lancet 2000;356:1307-12.

11. Pittet D. Improving compliance with hand hygiene in hospitals. Infect Control Hosp Epidemiol 2000;21:381-6.

12.Eksi F, Mehli M, Akgun S, et al. Evaluation of two different hand hygiene procedures during routine patient care. J Int Med Res 2010;38:2084-92.

13. Rosenthal VD, Guzman S, Safdar N. Reduction in nosocomial infection with improved hand hygiene in intensive care units of a tertiary care hospital in Argentina. Am J Infect Control 2005;33:392-7.

14. Rupp ME, Fitzgerald T, Puumala S, et al. Prospective, controlled, cross-over trial of alcohol-based hand gel in critical care units. Infect Control Hosp Epidemiol 2008;29:8-15.

15. Akyol A, Ulusoy H, Ozen I. Handwashing: a simple, economical and effective method for preventing nosocomial infections in intensive care units. J Hosp Infect 2006;62:395-405

16. Thi Anh Thu L, Thi Hong Thoa V, Thi Van Trang D, et al. Cost-effectiveness of a hand hygiene program on health care-associated infections in intensive care patients at a tertiary care hospital in Vietnam. Am J Infect Control 2015, Oct 1 [Epub ahead of print]

17. Allegranzi B, Pittet D. Role of hand hygiene in healthcare-associated infection prevention. J Hosp Infect 2009;73:305-15. 


\title{
Наблюдение за частотой и антимикробной чувствительностью па- тогенов на поверхности рук медицинского персонала в специали- зированных больницах
}

\author{
Евангелия Нена, Анастасио Целебонис, Кристос Николайдис, Теохарис Константини- \\ дис, Кристос Контойоргис, Мария Панополу, Теодор Константинидис
}

Фракийский университет им. Демокрита, Александруполис, Греция

\section{Для корреспонденции: \\ Евангелия Нена, Лаборатория гигиены и защиты окружающей среды, Медицинский факультет, Фракийский университет им. Демокрита, \\ 6th Km Alexandroupolis- Makris, Dragana 68100 \\ Alexandroupolis, Greece \\ E-mail: enena@med.duth.gr \\ тел.: +302551030638}

Дата получения: 23.12. 2015 г. Дата приемки: 20.06.2016 г. Дата онлайн публикации: 08.08.2016 г.

Дата публикации: 30.09.2016 г.

Ключевые слова: больничная гигиена, пробы с рук,

лекарственная резистентность

Цитаты: Нена Е., Целебонис А., Николайдис С., Константинидис Т., Контойоргис К., Панополу М., Константинидис Т.К. Наблюдение за частотой и антимикробной чувствительностью патогенов на поверхности рук медицинского персонала в специализированных больницах.

Журнал "Folia Medica" 2016;58(3);200-205;

doi: 10.1515/folmed-2016-0028
Цель: Наблюдение за микробами (с акцентом на лекарственную резистентность) на поверхности рук персонала в четырех отделениях специализированной больницы (интенсивная терапия, неонатальное, внутренняя медицина и хирургическое отделение) и анализ различий в разрезе по отделениям, профессиям и гендерному признаку.

Метод: Были взяты пробы с рук 125 медицинских работников, затем последовала изоляция, идентификация и определение антибиотической резистентности разных видов микробов.

Результаты: Стафилококки (Staphylococcus spp) являются самой превалирующей группой микробов (76/125, 60.8\%), за ними следуют грамотрицательные патогены (45.6\%). У персонала, занятого в отделении интенсивной терапии, наблюдается большая вероятность заражения грамотрицательными бактериями [OR 3.627 (95\% Cl 1.220-10.782)], независимо от пола и профессии. Наличие Staphylococcus spp связано с работой в отделении внутренней медицины [OR 6.976 (95\% Cl 1.767-25.540)] и в хирургическом отделении [OR 5.795 (95\% Cl 1.586-21.178)]. Стафилококки встречаются чаще у мужчин, чем у женщин (81.3\% и 54.9\%, $p=0.008)$, а также чаще у врачей, чем у медсестер $(76.9 \%$ и $54.8 \%, p=0.019)$.

В большинстве грамнегативных изолятов (56.1\%) был изолирован как минимум один штамм с мультилекарственной резистентностью (MDR) или резистентностью к широкому спектру лекарств (XDR). На поверхности рук медсестер была установлена статистически значимая более высокая степень распространения XDR грамнегативных микробов (22.2\% у медсестер и 2.3\% у врачей, $\mathrm{p}=0.014)$. Было выявлено всего 2 метициллинрезистентных золотистых стафилококка (MRSA) из числа 12 положительных проб на наличие Staphylococcus aureus.

Заключение: Персонал, работающий в отделении интенсивной терапии, в большой степени подвержен заражению грамнегативными, нежели грампозитивными бактериями. MDR и XDR являются превалирующим видом и связаны с профессией медсестры. 